\title{
PENGARUH STIMULASI MENDENGARKAN LAGU DAN BERNYAYI TERHADAP PERKEMBANGAN BERBAHASA PADA ANAK USIA DINI
}

\author{
Ning Setio Wati \\ Institut Agama Islam Negeri (IAIN) Metro \\ Jl. Ki Hajar Dewantara 15 A Iring Mulyo Kota Metro, Lampung \\ ningsetiowati87@gmail.com
}

\begin{abstract}
Language is one of aspects that need to be incressed for the development of early childhood. This study aims at determining the effect of listening and singing the songs on language development in early childhood at TPA Permata Bunda Metro. The design of this research is Quasi experiment with Nonequivalent control group pretest - postest design. The data collecting technique used observation sheet with a population of 10 children. The sampling technique was sampling random of 5 children. The normality test used Shapiro wilk. The data analized use Mann Whiney $U$ test. The result shows that the value of Mann Whiney $U$ test on language development with significant value $0.01(P<0.05)$, it can be concluded that listening and singing the song activity can influence to language development for early childhood.
\end{abstract}

Keywords: Early Childhood, Language development, Listening and singing the songs

\begin{abstract}
Abstrak
Bahasa merupakan salah satu aspek yang perlu ditinggkatkan bagi perkembangan anak usia dini. Penelitian ini bertujuan untuk mengetahui pengaruh dari kegiatan mendengarkan lagu dan bernyanyi terhadap perkembangan bahasa pada anak usia dini di TPA Permata Bunda kota Metro. Desain penelitian ini adalah Quasi experiment dengan rancangan Nonequivalent control group pretest - postest design. Pengumpulan data menggunakan lembar observasi dengan populasi 10 anak. pengambilan sampel menggunakan tehnik sampling random yaitu 5 anak. Uji normalitas menggunakan Shapiro wilk. Analisa data menggunakan Mann Whiney $U$ test. Hasil uji Mann Whiney U Test pada perkembangan bahasa dengan nilai signifikan 0,01 $(P<0,05)$, dapat disimpulkan bahwa kegiatan mendengarkan lagu dan bernyanyi berpengaruh terhadap perkembangan bahasa bagi anak usia dini.
\end{abstract}

Kata Kunci: Anak Usia Dini, Perkembangan Bahasa, Menyanyi dan mendengarkan Lagu

\section{Pendahuluan}

Anak sekelompok usia dini merupakan anak-anak yang sedang memiliki rentan usia dari usia 0 sampai dengan 6 tahun. Sebagaimana dinyatakan oleh Khadijah anak usia dini ialah ialah anak yang berumur 0-6 tahun yang memiliki pertumbuhan dan perkembangan yang lebih pesat dan fundamental pada awalawal tahun kehidupannya. ${ }^{1}$ Dimasa usianya tersebut, anak usia dini memiliki karakter sebagai individu yang unik dalam proses pertumbuhan dan perkembangan dalam beberapa aspek, seperti: fisik, kognitif,

1 Khadijah, Pengembangan kognitif anak usia dini (Medan: Perdana Publishing, 2016), 11. 
sosial emosional, kreatifitas, bahasa dan komunikasi yang khusus sesuai dengan tahapan yang sedang dilalui oleh anak tersebut. Lebih lanjut Desi Indratini menyatakan bahwa anak usia dini adalah sosok individu yang sedang menjalani suatu proses perkembangan dengan pesat dan sangat fundamental bagi kehidupan selanjutnya. ${ }^{2}$ Proses perkembangan dari masa anak usia dini sering disebut dengan masa keemasan atau disebut dengan Golden Age. Dikarenakan anak-anak mengalami pertumbuhandan perkembanganyangcukup pesat. Pada masa keemasan tersebut, mereka siap mengalami masa terjadinya kematangan fungsi-fungsi fisik dan psikis yang siap merespon stimulasi atau rangsangan yang diberikan oleh lingkungan.

Lebih lanjut, anak usia dini memiliki berbagai macam potensi dasar yang harus dikembangkan. Dalam mengembangkan potensi dasar pada anak usia dini merupakan sebagai landasan utama untuk dapat menempuh kehidupan pada langkah selanjutnaya dengan cara yang lebih baik, dan dapat tumbuh kembang sebagai manusia dewasa seutuhnya. Dikarenakan anak usia dini masih memiliki rentan usia yang sangat muda, anak-anak tersebut masih memiliki rasa ketergantungan kepada orang dewasa baik itu orang tua yang berada dirumah ataupun para pendidik yang berada di sekolah. Oleh karena itu, peran sebagai orang tua ataupun pendidik memiliki peran yang sangat penting untuk mengembangkan potensi dasar dari anak tersebut. Apabila pengembangan potensi dilakukan dengan cara yang tidak tepat, maka anak-anak tersebut akan mengalami dampak negatif dari proses tersebut yang dapat terbawa sampai anak tersebut tumbuh dewasa.

2 Dewi Indratini, Upaya Peningkatan Kemampuan Berbahasa Melalui Nyanyian/Lagu Bagi Anak Usia Dini Sebuah Penelitian Tindakan Kelas di TK Aisyiyah I Pandean, Ngemplak Boyolali Tahun Ajaran 2009/2010 (Surakata: Universitas Muhammadiyah, 2010), 1.
Salah satu potensi dasar yang perlu dikembangkan sejak dini adalah potensi berbahasa. Tesya dalam Masitoh, dkk., mengemukakan bahasa adalah bentuk komunikasi, perasaan dan pikiran manusia disimbolkan agar dapat menyampaikan arti kepada orang lain. ${ }^{3}$ Dimana bahasa memiliki peran penting dalam perkembangan intelektual, sosial, dan emosional anak ${ }^{4}$. Sementara itu, menurut Puji dan Hermawati menyebutkan beberapa faktor yang mempengaruhi perkembangan berbahasa anak diantaranya: faktor kesehatan, faktor intelegensi, faktor status sosial ekonomi, faktor jenis kelamin, faktor hubungan keluarga, faktor jumlah anggota keluarga, faktor posisi urutan kelahiran, dan faktor kedwibahasaan / penggunaan dua bahasa. ${ }^{5}$ Dalam proses pengembangan bahasa anak diharapkan dapat membantu anak usia dini untukmengenaldirinya, danmengemukakan perasaanya kepada orang lain.

Anak usia dini merupakan anakanak yang memiliki masa emas (Golden age). Dikarenakan pada masa tersebut, anak usia dini memiliki keelastisan pada otak kanan untuk belajar bahasa, sehingga penyerapan pemerolehan bahasa tersebut lebih mudah. Selaras dengan pendapat Anita dalam Syaodih bahwa dimasa usia dini merupakan masa berkembang pesat untuk menguasai perbendaharaan kata. Dimana pada awal masa ini, anak sudah menguasai sekitar 2500 kata, dan pada masa kanak-kanak akhir (kira-kira usia 11-12 tahun) anak telah dapat

3 Tesya Cahyani Kusuma, “Gambaran Tentang Peranan Kegiatan Bernyanyi dalam Pengembangan Bahasa Anak Usia Dini di Taman Kanak-kanak Budi Mulia," Jurnal Pesona Paud 1, no. 2 (1 Juli 2012): 2.

4 Khotijah, "Strategi Pengembangan Bahasa pada Anak Usia Dini," Elementary: Jurnal Ilmiah Pendidikan Dasar 2, no. 2 (2016): 27.

5 Puji Lestari dan Hermawati Dwi Susari, “Pengembangan Berbahasa pada Anak Usia 4-5 Tahun Melalui Metode Bermain Kartu Huruf di TK PSM 2 Kawedanan Magetan Tahun Pelajaran 2014/2015," Jurnal CARE (Children Advisory Research and Education) 3, no. 2 (2016): 37. 
menguasai sekitar 5000 kata. $^{6}$ Dengan kata lain, ketika anak usia dini mampu menguasai perbendaharaan kata, mereka mulai belajar untuk melakukan komunikasi dengan orang disekitarnya. Hal ini merupakan tujuan dari pengembangan bahasa dari anak usia dini.

Sementara itu, proses dari berbahasa akan diikuti dengan proses berbicara. Dalam proses berbahasa diperlukan penggunaan tanda-tanda dalam sebuah tatabahasa yang biasanya disebut dengan struktur aturan ataupun pola dalam kalimat. Proses berbahasa tersebut akan dapat dimengerti ketika ungkapan dari perbendaharaan kata yang disampaikan jelas. Penguasaan perbendaharaan kosa kata sangat berpengaruh dalam proses berbicara. Jika, anak belum menguasai perbendaharaan kosa kata dalam berbicara, maka anak tidak dapat melakukan proses berbicara. Enny Zubaidah mengungkapkan ada dua bentuk proses yang menentukan kesiapan anak dalam berbicara, yaitu (1) perkembangan kognitif dan (2) perkembangan bahasa. $^{7}$ Perkembangan kognitif merupakan adanya proses keseimbangan dan ketidak seimbangan yang berlangsung secara terus menerus. Dalam proses perkembangan kognitif memiliki beberapa tahap yang harus dilalui seperti tahap sensori motor, preoperasional, operasional konkret, dan operasional formal. Dalam tahap perkembangan kognitif akan diikuti dengan perkembangan bahasa anak. Sedangkan, perkembangan bahasa anak akan ditempuh dengan cara yang sistematis dan berkembang bersama dengan pertambahan usia anak.

Lebih lanjut, Dewi Pangastuti mengutarakan perkembangan bahasa pada anak dibagi dalam dua periode besar, yaitu:

6 Anita Rosalina, "Peningkatan Kemampuan Bahasa Anak Usia Dini Melalui Kegiatan Bermain," Psychoidea 9, no. 1 (2011): 20.

7 Enny Zubaidah, "Perkembangan bahasa anak usia dini dan teknik pengembangan di sekolah," Cakrawala Pendidikan, no. 3 (2004): 462.
(1) periode Prelinguistik (0-1 tahun), (2) periode Linguistik (1-5 tahun). ${ }^{8}$ Pada periode Prelinguistik anak masih berada pada rentan usia 0 sampai 1 tahun. Pada masa usia tersebut anak memiliki suara pertama yang dikeluarkan, seperti: a, e, i, o, u (huruf vocal) dan b, p, n, k, r (huruf konsonan). Sementara untuk periode Linguistik anak sudah memiliki kemampuan lebih dalam mengucapkan kata-kata yang pertama untuk menyatakan pikiran anak secara kompleks. Periode linguistik terbagi dalam tiga fase besar, yaitu: (1) Fase satu kata atau Holofrase, (2) lebih dari satu kata (3) Fase ketiga adalah fase diferensiasi.

Dalam meningkatkan kemampuan berbahasa pada anak usia dini dibutuhkan kegiatan yang dapat merangsang kemampuan berbahasa anak, seperti stimulasi dan bimbingan yang akan meningkatkan perkembangan bahasa anak sehingga menjadi dasar utama untuk perkembangan pada bahasa anak yang selanjutnya9. Adapun contoh kegiatan dalam pengembangan bahasa pada anak usia dini adalah mendengarkan lagu dan bernyayi. Menurut Farida, dkk., dalam Burhan mendengarkan adalah suatu proses menangkap, memahami, dan mengingat dengan sebaikbaiknya apa yang didengarnya atau sesuatu yang dikatakan oleh orang lain kepadanya. ${ }^{10}$ Melaui kegiatan mendengarkan lagu, anak akan menangkap, memahami, dan mengingat kata demi kata pada saat mendengarkan lagu tersebut. Sementara itu, Sihombing menyatakan bahwa bernyanyi

8 Dewi Pangastuti, "Pengaruh Musik Dangdut Terhadap Perkembangan Bahasa Anak Di TK Dharma Wanita Madiun 2014/2015," Prosiding Ilmu Pendidikan 1, no. 2 (2016): 223.

9 Akla, "Desain Pembelajaran Bahasa Arab berbasis Penanaman Karakter untuk Anak Usia Dini," Elementary: Jurnal Ilmiah Pendidikan Dasar 3, no. 2 (2017): 144.

${ }_{10}$ Farida Ariani, Slamet Mulyana, dan Asep, Pelajaran Mendengarkan (Jakarta: Pusat Pengembangan dan Pemberdayaan Pendidikan dan Tenaga Kependidikan Bahasa, 2009), 6. 
merupakan salah satu fungsi seni sebagai media komunikasi atau sarana dan cara untuk berhubungan dengan anak. ${ }^{11}$ Dalam proses bernyanyi, anak-anak akan mencoba menirukan ucapan dalam setiap kata. Oleh karena itu, anak-anak dapat meningkatkan perbendaharaan kata, kreativitas serta kemampuan anak berimajinasi dapat mengembangkan daya pikir anak sehingga perkembangan inteligensinya dapat berlangsung dengan baik.

Kegiatan mendengarkan lagu dan bernyanyi sangat melekat erat dan tidak dapat dipisahkan terutama dalam memberikan pembelajaran kepada anak usia dini. Pembelajaran mendengarkan lagu dan bernyanyi merupakan sebuah kegiatan dalam bermain sambil belajar dan belajar sambil bermain, aktivitas yang dilakukan melalui mendengarkan lagu dan bernyanyi diharapkan akan menyenangkan anak sekaligus menyentuh perkembangan bahasa, kepekaan akan irama musik, perkembangan motorik, rasa percaya diri, serta keberanian mengambil resiko. Karena itu perlu adanya suatu kegiatan yang dapat melatih para pendidik anak usia dini dalam memberikan perangsangan pada anak melalui mendengarkan lagu dan bernyanyi.

Seperti penelitian terdahulu yang dilakukan oleh Umu Habibah tentang Upaya Meningkatkan Kosa Kata Bahasa Inggris Melalui Kegiatan Bernyanyi Pada Anak Kelompok A TK Pertiwi 1 Jirapan. ${ }^{12}$ Penelitian tersebut dilakukan dengan menggunakan metode penelitian tindakan kelas. Teknik analisis data terdiri dari tiga alur kegiatan, yaitu reduksi data, penyajian

11 Lamhot Basani Sehombing, "Suatu Pendekatan Strategi Dan Metode Pendidikan Seni Melalui Kegiatan Bernyanyi Sebagai Aspek-Aspek Pengembangan Pendidikan Karakter Pada Anak Usia Dini," Generasi Kampus 6, no. 2 (2017): 3.

${ }^{12}$ Umu Habibah, "Upaya Meningkatkan Kosa Kata Bahasa Inggris Melalui Kegiatan Bernyanyi Pada Anak Kelompok A TK Pertiwi I Jirapan 2012/2013" (Universitas Muhammadiyah Surakarta, 2012), 1. data serta penarikan kesimpulan. Dari hasil penelitian menyimpulkan adanya peningkatan penguasaan kosa kata bahasa Inggris pada anak melalui kegiatan bernyanyi. Selanjutnya, Penelitian yang dilakukan oleh Renita Septi Anggraini tentang Peningkatan Kosa Kata Bahasa Inggris Pada Anak Kelompok B Melalui Metode Bermain Gerak dan Lagu di TK Pertiwi Kecamatan Gunungmas Kabupaten Jember. ${ }^{13}$ Tujuan dari penelitian tersebut adalah (1) mendeskripsikan penerapan metode permainan gerak dan lagu untuk meningkatkan penguasaan kosa kata bahasa Inggris pada anak kelompok B di TK Pertiwi, (2) meningkatkan kemampuan penguasaan kosa katabahasa Inggris pada anak kelompok B di TK Pertiwi. Jenis penelitian yang dilakukan adalah Penelitian Tindakan Kelas yang terdiri dari pendahuluan, perencanaan, pelaksanaan, tindakan dan refleksi. Dari hasil penelitian diperoleh kesimpulan bahwa Penerapan metode bermain gerak dan lagu dapat meningkatkan penguasaan kosa kata bahasa inggris anak kelompok B TK Pertiwi Tahun Pelajaran 2016/2017.

Sementara itu, berdasarkan hasil pengamatan dari kegiatan belajar di Tempat Pendidikan Anak (TPA) Permata Bunda Iringmulyo Kecamatan Metro Timur Kota Metro menunjukkan bahwa anak-anak di TPAPermata Bunda masih merasa malu-malu dalam mengekspresikan dan menyalurkan rasa senang ataupun kagum. Terlebih lagi, para pendidik hanya terfokus pada memberikan beberapa macam permainan anak-anak yang menimbulkan efek anakanak menjadi pasif dalam mengekspresikan perasaan senang, lucu, dan kagum dalam kata-kata. Pada setiap kegiatan mereka hanya disibukkan dengan permainan dan

13 Renita Septi Anggraini, "Peningkatan Kosa Kata Bahasa Inggris Pada Anak Kelompok B Melalui Metode Bermain Gerak dan Lagu di TK Pertiwi Kecamatan Gunungmas Kabupaten Jember" (Universitas Jember, 2017), 7. 
kurang berinteraksi dengan yang lainya. Hal terpenting yang diterapkan oleh para pendidik adalah anak-anak tidak rewel atau menangis selama proses penitipan.

Bertolak dari permasalahan diatas, eksperiment akan dilakukan untuk mengetahui kegiatan mendengarkan lagu dan bernyanyi dapat memberikan pengaruh dalam mengembangkan bahasa pada anak usia dini. Dengan kata lain, penulis tertarik ingin meneliti tentang "Pengaruh Stimulasi Mendengarkan Lagu Dan Bernyayi Terhadap Kemampuan Berbahasa Pada Anak Usia Dini".

\section{Metodologi}

Disain penelitian ini menggunakan Design Quasi ekperiment. Jenis rancangan yang akan digunakan adalah Nonequivalent control group pretest-posttest design. Sementara itu, populasi dari penelitian ini adalah anakanak usia dini dari TPA Permata Bunda Iringmulyo Kecamatan Metro Timur Kota Metro sebanyak 10 anak. Dari 10 anak peneliti memilih 5 anak sebagai sampel. Dalam melakukan pengambilan sampel, peneliti menggunakan metode Simple Random Sampling. Dengan cara menulis nama anak-anak tersebut dilembaran kertas kecil, kemudian dilipat dan diambil secara acak sebanyak 5 kertas.

Penelitian ini dilaksanakan pada 6 November 2017 sampai dengan 30 November 2017. Pengumpulan data pada penelitian ini dilakukan dengan menggunakan lembar observasi yang terdiri dari bagian I identitas responden, bagian II untuk lembar identifikasi perkembangan bahasa. Lembar observasi aspek perkembangan bahasa terdiri dari 25 item pernyataan. Skala pengukuran data yang digunakan adalah skala Likert yang terdiri dari jawaban baik, cukup, dan kurang.

Data awal dikumpulkan dengan lembar observasi pretest. Selanjutnya respondendiberikankegiatanmendengarkan lagu dan bernyanyi pada kelompok eksperimen yang akan dilakukan oleh peneliti, setiap pertemuan selama 40 menit dengan mendengarkan 5 lagu dan bernyanyi bersama-sama. Pertemuan dilakukan sebanyak 3 kali. Sesudah pemberian intervensi, data akhir diambil dengan lembar observasi posttest pada masing-masing kelompok. Pada penelitian ini pengolahan data menggunakan tahap-tahap pengolahan data sebagai berikut: editing, coding, data entry, tabulating.

\section{Pembahasan}

Tabel 1. Distribusi Frekuensi Karakteristik

\begin{tabular}{|c|c|c|c|c|c|}
\hline \multicolumn{6}{|c|}{ Responden } \\
\hline \multirow[t]{2}{*}{ No } & \multirow{2}{*}{$\begin{array}{l}\text { Karakteristik } \\
\text { Responden }\end{array}$} & \multicolumn{2}{|c|}{$\begin{array}{c}\text { Kelompok } \\
\text { Eksperimen }\end{array}$} & \multicolumn{2}{|c|}{$\begin{array}{c}\text { Kelompok } \\
\text { Kontrol }\end{array}$} \\
\hline & & Frekuensi & $\%$ & Frekuensi & $\%$ \\
\hline \multirow{5}{*}{1} & Usia & & & & \\
\hline & $0-1$ & 1 & 20 & 2 & 40 \\
\hline & $2-3$ & 3 & 60 & 2 & 40 \\
\hline & $4-5$ & 1 & 20 & 1 & 20 \\
\hline & Total & 5 & 100 & 5 & 100 \\
\hline \multirow{4}{*}{2} & $\begin{array}{l}\text { Jenis } \\
\text { Kelamin }\end{array}$ & & & & \\
\hline & Laki-laki & 4 & 80 & 3 & 60 \\
\hline & Perempuan & 1 & 20 & 2 & 40 \\
\hline & Total & 5 & 100 & 5 & 100 \\
\hline \multirow{5}{*}{3} & $\begin{array}{l}\text { Pendidikan } \\
\text { Orang Tua }\end{array}$ & & & & \\
\hline & SMA & 1 & 20 & 1 & 20 \\
\hline & $\mathrm{S} 1$ & 3 & 60 & 3 & 60 \\
\hline & S2 & 1 & 20 & 1 & 20 \\
\hline & Total & 5 & 100 & 5 & 100 \\
\hline
\end{tabular}

Berdasarkan tabel.1 dapat dideskripsikan bahwa jumlah responden pada kelompok eksperimen sebagian besar berusia 2-3 tahun sebanyak 3 anak (60\%) dan usia $0-1$ tahun hanya 1 anak (20\%), dan usia 4-3 tahun juga hanya terdapat 1 anak (20\%). Sedangkan untuk kelompok kontrol sebagian besar berusia 0-1 tahun 2 anak (40\%), dan 2-3 tahun sebanyak 2 anak (40\%), sementara usia 4-5 tahun hanya terdapat 1 anak (20\%). Sedangkan pada kelompok eksperimen sebagian besar adalah jenis kelamin laki-laki sebanyak 4 anak (80\%) dan jenis kelamin 
perempuan sebanyak 1 anak (20\%). Pada kelompok kontrol sebagian besar adalah jenis kelamin laki-laki sebanyak 3 anak $(60 \%)$, sedangkan jenis kelamin perempuan sebanyak 2 anak (40\%).

Berdasarkan karakteristik pendidikan orang tua mayoritas berpendidikan S1 yaitu 3 orang (60\%) untuk kelompok eksperimen, Sementara itu, untuk kelompok kontrol juga memiliki prosentase yang sama dengan kelompok ekperimen sebanyak 3 orang (60\%). Karakteristik responden berdasarkan pekerjaan, terbanyak adalah sebagai Pegawai 4 orang $(80 \%)$ untuk kelompok eksperimen dan untuk kelompok kontrol jumlahnya 5 orang $(100 \%)$.

Lebih lanjut, data yang diperoleh pada sampel harus diuji normalitas terlebih dahu. Uji normalitas data menggunakan Shapiro Wilk. Pada data perkembangan bahasa data posttest eksperimen tidak terdistribusi normal Sehingga analisis data yang digunakan peneliti adalah teknik nonparametrik yaitu Uji Wilcoxon dan Uji Mann Whitney U-test.

Tabel 2. Hasil pretest- posttest perkembangan bahasa dengan uji MannWhitney Utest

\begin{tabular}{clcccc}
\hline & Variable & Mean & $\begin{array}{c}\text { Sum of } \\
\text { Ranks }\end{array}$ & Df & $\begin{array}{c}\text { Sig. } \\
\text { (2-tailed) }\end{array}$ \\
\cline { 3 - 5 } $\begin{array}{c}\text { Perkem- } \\
\text { bangan } \\
\text { Bahasa }\end{array}$ & $\begin{array}{l}\text { Kelompok } \\
\text { Ekspe- } \\
\text { rimen }\end{array}$ & 22.64 & 306.40 & 5 & 0.01 \\
& & & & \\
Kelompok & 12.34 & 234.40 & 5 & \\
Kontrol
\end{tabular}

Pada Tabel 2. didapatkan bahwa hasil uji statistik dengan menggunakan MannWhitney U-Test, antara kelompok kontrol dengan kelompok eksperimen didapatkan nilai Asymp. Sig. (2-tailed) sebesar 0,01 (p $<0,05$ ). Hasil tersebut menunjukkan bahwa Ha diterima sedangkan Ho ditolak, yang berarti ada perbedaan yang bermakna pada nilai perkembangan bahasa pada anak TPA Permata Bunda antara kelompok kontrol dan kelompok eksperimen.
Selanjutnya, untuk distribusi frekuensi responden berdasarkan hasil lembar observasi pada aspek perkembangan bahasa adalah sebagai berikut (tabel 3).

Tabel 3. Distribusi frekuensi perubahan perkembangan bahasa anak TPA Permata Bunda

\begin{tabular}{ccccccccccc}
\hline & & \multicolumn{3}{c}{ Eksperimen } & \multicolumn{3}{c}{ Kontrol } \\
\cline { 3 - 11 } No & $\begin{array}{c}\text { Kate- } \\
\text { gori }\end{array}$ & \multicolumn{2}{c}{ Pretest } & \multicolumn{2}{c}{ Posttest } & \multicolumn{2}{c}{ Pretest } & \multicolumn{2}{c}{ Posttest } \\
\cline { 3 - 11 } & & $\begin{array}{c}\text { Fu- } \\
\text { ku- } \\
\text { ensi }\end{array}$ & $\begin{array}{c}\text { Fre- } \\
\text { ku- } \\
\text { ensi }\end{array}$ & $\begin{array}{c}\text { Fre- } \\
\text { ku- } \\
\text { ensi }\end{array}$ & $\begin{array}{c}\text { Fre- } \\
\text { ku- } \\
\text { ensi }\end{array}$ \\
\hline 1 & Baik & 2 & 40 & 4 & 80 & 1 & 20 & 2 & 40 \\
\hline 2 & Cukup & 3 & 60 & 1 & 20 & 4 & 80 & 3 & 60 \\
\hline 3 & Kurang & 0 & 0 & 0 & 0 & 0 & 0 & 0 & 0 \\
\hline & Total & 5 & 100 & 5 & 100 & 5 & 100 & 5 & 100 \\
\hline
\end{tabular}

Tabel 3 menunjukkan bahwa perkembangan bahasa anak-anak TPA Permata Bunda pada kelompok eksperimen, sebelum dilakukan intervensi kegiatan mendengarkan lagu dan bernyanyi terbanyak dengan kategori baik 2 anak (40\%), sedangkan setelah dilakukan intervensi perkembangan bahasa kelompok eksperimen anak meningkat dalam kategori baik sekali 4 anak (80\%). Pada kelompok kontrol frekuensi data sebelum dilakukan intervensi dengan kategori baik 1 anak $(20 \%)$ dan setelah dilakukan intervensi pada kategori baik meningkat menjadi 2 anak (40\%). Maka dapat dilihat frekuensi perkembangan bahasa setelah dilakukan intervensi pada kelompok eksperimen dengan kategori baik meningkat sebanyak $40 \%$ sedangkan pada kelompok kontrol dengan kategori baik meningkat sebanyak $20 \%$ dari frekuensi sebelumnya.

\section{Perkembangan bahasa}

Pada penelitian didapatkan sebagian besar responden mengalami peningkatan kemampuan berbahasa, pada kelompok kontrol maupun kelompok eksperimen. Hal ini terbukti pada kenaikan hasil pengukuran pada responden yang menjawab benar terutama pada kelompok eksperimen yang telah diberi intervensi mendengarkan lagu 
dan bernyanyi. Begitu juga pada kelompok kontrol terdapat peningkatan responden yang menjawab benar setelah dilakukan posttest walaupun tidak signifikan (tabel 3).

Hasilujianalisis denganmenggunakan Mann Whitney U-test diperoleh nilai yang bermakna yaitu 0,01. Karena nilai pada uji beda Mann Whitney U-test diperoleh 0,01 lebih kecil dari 0,05 $(0,01<0,05)$, maka dapat disimpulkan bahwa kegiatan mendengarkan lagu dan bernyanyi berpengaruh pada perkembangan bahasa anak-anak TPA Permata Bunda. Kegiatan mendengarkan lagu dan bernyanyi juga efektif dalam pengajaran anak-anak TPA Permata Bunda yang lebih menonjolkan ekspresi senang dalam mengutarakan perasaan dalam kosa kata untuk memotivasi anak lebih aktif didalam kelas.

Hasil penelitian menunjukkan karakteristik responden kedua kelompok, mayoritas anak berusia 2-3 tahun yaitu 3 anak $(60 \%)$ untuk kelompok eksperimen dan kelompok kontrol 2 anak (40\%). Pada umumnya ketika anak berusia satu tahun, mereka sudah dapat mengucapkan satu atau dua patah kata. Sementara itu, pada saat anak sudah berusia dua tahun mereka sudah mulai belajar beberapa kata baru setiap hari. Sebagaimana diungkapkan oleh Khadijah dalam Sampel menyatakan bahwa sejak anak berusia dua tahun anak talah mampu belajar sekitar enam kata baru setiap harinya. ${ }^{14}$ Oleh karena itu, perkembangan bahasa bagi anak usia dini merupakan aspek penting yang harus diberikan bekal ataupun stimulasi yang baik untuk membantu mereka dalam membentuk gagasan-gagasan baru, mengungkapkan emosinya seperti ketika mereka marah ataupun gembira.

Tabel 3 menunjukkan bahwa perkembangan bahasa anak-anak TPA

14 Khadijah, Pengembangan kognitif anak usia dini, 25.
Permata Bunda pada kelompok eksperimen, sebelum dilakukan intervensi kegiatan mendengarkan lagu dan bernyanyi terbanyak dengan kategori baik 2 anak (40\%), sedangkan setelah dilakukan intervensi perkembangan bahasa kelompok eksperimen anak meningkat dalam kategori baik sekali 4 anak (80\%). Pada kelompok kontrol frekuensi data sebelum dilakukan intervensi dengan kategori baik 1 anak (20\%) dan setelah dilakukan intervensi pada kategori baik meningkat menjadi 2 anak (40\%). Maka dapat dilihat frekuensi perkembangan bahasa setelah dilakukan intervensi pada kelompok eksperimen dengan kategori baik meningkat sebanyak $40 \%$ sedangkan pada kelompok kontrol dengan kategori baik meningkat sebanyak $20 \%$ dari frekuensi sebelumnya.

\section{Perkembangan bahasa}

Pada penelitian didapatkan sebagian besar responden mengalami peningkatan kemampuan berbahasa, pada kelompok kontrol maupun kelompok eksperimen. Hal ini terbukti pada kenaikan hasil pengukuran pada responden yang menjawab benar terutama pada kelompok eksperimen yang telah diberi intervensi mendengarkan lagu dan bernyanyi. Begitu juga pada kelompok kontrol terdapat peningkatan responden yang menjawab benar setelah dilakukan posttest walaupun tidak signifikan (tabel 3).

Hasilujianalisisdenganmenggunakan Mann Whitney U-test diperoleh nilai yang bermakna yaitu 0,01. Karena nilai pada uji beda Mann Whitney U-test diperoleh 0,01 lebih kecil dari 0,05 $(0,01<0,05)$, maka dapat disimpulkan bahwa kegiatan mendengarkan lagu dan bernyanyi berpengaruh pada perkembangan bahasa anak-anak TPA Permata Bunda. Kegiatan mendengarkan lagu dan bernyanyi juga efektif dalam pengajaran anak-anak TPA Permata Bunda yang lebih menonjolkan ekspresi senang dalam mengutarakan perasaan dalam kosa 
kata untuk memotivasi anak lebih aktif didalam kelas.

Hasil penelitian menunjukkan karakteristik responden kedua kelompok, mayoritas anak berusia 2-3 tahun yaitu 3 anak $(60 \%)$ untuk kelompok eksperimen dan kelompok kontrol 2 anak (40\%). Pada umumnya ketika anak berusia satu tahun, mereka sudah dapat mengucapkan satu atau dua patah kata. Sementara itu, pada saat anak sudah berusia dua tahun mereka sudah mulai belajar beberapa kata baru setiap hari. Sebagaimana diungkapkan oleh Khadijah dalam Sampel menyatakan bahwa sejak anak berusia dua tahun anak talah mampu belajar sekitar enam kata baru setiap harinya. ${ }^{15}$ Oleh karena itu, perkembangan bahasa bagi anak usia dini merupakan aspek penting yang harus diberikan bekal ataupun stimulasi yang baik untuk membantu mereka dalam membentuk gagasan-gagasan baru, mengungkapkan emosinya seperti ketika mereka marah ataupun gembira.

\section{Kesimpulan}

Hasil observasi anak usia dini di TPA Permata Bunda Metro Timur pada kelompok eksperimen didapatkan perkembangan bahasa (pretest) dengan kategori baik ada 2 anak (40\%).Setelah dilakukanintervensipada kelompok eksperimen nilai perkembangan bahasa akhir (posttest) dengan kategori baik sekali sebanyak 4 anak (80\%). Sementara itu, Kegiatan mendengarkan lagu dan bernyanyi mempunyai pengaruh dalam meningkatkan perkembangan bahasa, hal ini dibuktikan dengan nilai sig. (2-tialed) pada perkembangan bahasa adalah 0,01.

\section{Saran}

Tempat Penitipan Anak (TPA) merupakan salah satu tempat pendidikan nonformal bagi anak usia dini. Sebagaimana TPA memiliki dua tujuan yaitu mengasuh dan mendidik anak usia dini, dikarenakan

\footnotetext{
${ }^{15}$ Khadijah, 25.
}

kebanyakan orang tua dari anak tersebut memiliki kesibukan tersendiri. Oleh karen itu TPA harus memiliki metode yang efektif dalam mengasuh dan mendidik anakanak usia dini. Metode yang diberikan harus menarik dan tidak monoton untuk mengomptimalkan tumbuh kembang peserta didiknya. Terutama bagi peserta didik, diharapkan dapat menerapkan metode stimulasi yang tepat dalam mengoptimalkan perkembangan anak, khususnya pada perkembangan bahasa.

Untuk peneliti selanjutnya, diharapkan dapat menggunakan metode yang lebih menarik dan memiliki persiapan yang lebih maksimal untuk mendapatkan hasil yang optimal. Selanjutnya, peneliti dapat melibatkan orang tua anak, sehingga dapat memberikan informasi yang lebih akurat mengenai perkembangan anaknya dan mengkhususkan lembar observasi sesuai dengan umur anak. Peneliti menyarankan bagi peneliti selanjutnya untuk dapat memperhatikan kelemahan dan kelebihan dalam penelitian ini, sehingga dapat menjadi pertimbangan dalam penelitian selanjutnya.

\section{Daftar Pustaka}

Akla. "Desain Pembelajaran Bahasa Arab berbasis Penanaman Karakter untuk Anak Usia Dini." Elementary: Jurnal Ilmiah Pendidikan Dasar 3, no. 2 (2017).

Ariani, Farida, Slamet Mulyana, dan Asep. Pelajaran Mendengarkan. Jakarta: Pusat Pengembangan dan Pemberdayaan Pendidikandan Tenaga Kependidikan Bahasa, 2009.

Habibah, Umu. “Upaya Meningkatkan Kosa Kata Bahasa Inggris Melalui Kegiatan Bernyanyi Pada Anak Kelompok A TK Pertiwi I Jirapan 2012/2013." PhD Thesis, Universitas Muhammadiyah Surakarta, 2012.

Indratini, Dewi. Upaya Peningkatan Kemampuan Berbahasa Melalui 
Nyanyian/Lagu Bagi Anak Usia Dini Sebuah Penelitian Tindakan Kelas di TK Aisyiyah I Pandean, Ngemplak Boyolali Tahun Ajaran 2009/2010. Surakata: Universitas Muhammadiyah, 2010.

Khadijah. Pengembangan kognitifanakusiadini. Medan: Perdana Publishing, 2016.

Khotijah. "Strategi Pengembangan Bahasa pada Anak Usia Dini." Elementary: Jurnal Ilmiah Pendidikan Dasar 2, no. 2 (2016).

Kusuma, Tesya Cahyani. “Gambaran Tentang Peranan Kegiatan Bernyanyi dalam Pengembangan Bahasa Anak Usia Dini di Taman Kanak-kanak Budi Mulia." Jurnal Pesona Paud 1, no. 2 (1 Juli 2012).

Lestari, Puji, dan Hermawati Dwi Susari. "Pengembangan Berbahasa pada Anak Usia 4-5 Tahun Melalui Metode Bermain Kartu Huruf di TK PSM 2 Kawedanan Magetan Tahun Pelajaran 2014/2015." Jurnal CARE (Children Advisory Research and Education) 3, no. 2 (2016).

Pangastuti, Dewi. "Pengaruh Musik Dangdut Terhadap Perkembangan Bahasa Anak Di TK Dharma Wanita Madiun 2014/2015." Prosiding Ilmu Pendidikan 1, no. 2 (2016).

Renita Septi Anggraini. “Peningkatan Kosa Kata Bahasa Inggris Pada Anak Kelompok B Melalui Metode Bermain Gerak dan Lagu di TK Pertiwi Kecamatan Gunungmas Kabupaten Jember." Universitas Jember, 2017.

Rosalina, Anita. "Peningkatan Kemampuan Bahasa Anak Usia Dini Melalui Kegiatan Bermain." Psychoidea 9, no. 1 (2011).

Sehombing, Lamhot Basani. "Suatu Pendekatan Strategi Dan Metode Pendidikan Seni Melalui Kegiatan Bernyanyi Sebagai Aspek-Aspek
Pengembangan Pendidikan Karakter Pada Anak Usia Dini." Generasi Kampus 6, no. 2 (2017).

Zubaidah, Enny. "Perkembanganbahasaanak usia dini dan teknik pengembangan di sekolah." Cakrawala Pendidikan, no. 3 (2004). 
84| Flementitiry Vol. 4 Edisi Januari-Juni 2018 